\title{
MENCARI CELAH PENANAMAN NILAI-NILAI PANCASILA PADA GENERASI MILENIAL
}

\author{
Nichi Hana Karlina \\ Fakultas Komunikasi dan Desain, Universitas Informatika dan Bisnis Indonesia \\ email: nichi.hana@yahoo.com
}

\begin{abstract}
Abstrak
Bagi generasi milenial, penggunaan gadget sudah menjadi suatu gaya hidup bahkan media sosial kini telah menjadi ruang komunikasi. Generasi milenial atau generasi $\mathrm{Z}$ adalah mereka yang lahir setelah tahun 1980, memiliki kecenderungan spesifik pada pandangan politik, komunikasi dan cara pandang terhadap isu-isu dunia. Begitu pula dengan cara pandang mereka terhadap nilai-nilai Pancasila yang disinyalir mulai memudar.

Tujuan penelitian ini adalah mengetahui gambaran generasi milenial Indonesia agar dapat merancang strategi yang tepat dalam upaya membumikan Pancasila. Agar Pancasila tidak hanya dinilai sebagai ideologi negara, tetapi juga sebagai pandangan hidup, terutama dikalangan anak muda generasi milenial.

Metode penelitian pada penelitian ini adalah penelitian kualitatif, data penelitian diperoleh dari hasil studi literatur dan Focus Discussion Group (FDG) yang diadakan oleh UKP-PIP (Unit Kerja Presiden Pembinaan Ideologi Pancasila) pada tanggal 29 Desember 2017 di Luxton Hotel Bandung, untuk mengetahui pendapat dari berbagai kalangan, komunitas dan profesi yang terkait dengan generasi milenial.

Dengan mengetahui gambaran yang utuh mengenai generasi milenial, diharapkan mampu merancang strategi yang tepat dalam upaya membumikan Pancasila, sehingga dapat menciptakan generasi-generasi Indonesia yang berbudi luhur yang berlandaskan Pancasila.
\end{abstract}

Kata Kunci : Pancasila, Generasi, Milenial

\begin{abstract}
For millenial generation, the use of gadgets has become a lifestyle even social media has now become a communication space. Millennial or $Z$ generations are those born after the 1980s, have specific tendencies on political views, communication and worldviews on world issues. Similarly, their perspective on the values of Pancasila, which allegedly began to fade.

The purpose of this research is to know the description of millenial generation of Indonesia in order to design the right strategy in effort to ground Pancasila. So that Pancasila is not only considered as the state ideology, but also as a view of life, especially among millennial youth.

The research method in this research is qualitative research, the research data is obtained from the results of literature study and Focus Discussion Group (FDG) held by UKP-PIP (Presidential Work Unit of Ideology Development of Pancasila) on December 29, 2017 at Luxton Hotel Bandung, to know the opinion from various circles, communities and professions associated with millennial generation.

By knowing the full picture of the millennial generation, it is hoped that they will be able to design the right strategy in the effort to ground Pancasila, so as to create the virtuous generation of Indonesia based on Pancasila.
\end{abstract}

Keywords: Pancasila, Generation, Millenial 


\section{PENDAhuluan}

Begitu lama sosialisasi nilai-nilai Pancasila dirumuskan dan dilancarkan dari pusaran pikiran dan pengalaman orang tua, meski sasaran terpenting upaya tersebut adalah kaum muda. Kalangan remaja dan kaum muda umumnya cenderung dijadikan objek yang pasif, bukannya subjek yang aktif. Bentukbentuk penataran di Sekolah dan Kampus selama Orde Baru adalah buktinya. Bukan tidak mungkin program demikian malah kontraproduktif.

Perkembangan yang pesat dalam bidang informasi dan teknologi komunikasi, mobile communication device serta internet, yang diterapkan pada sebuah gadget. Penggunaan gadget mempunyai dampak positif dan dampak negatif bahkan mampu merubah konteks kehidupan budaya dan masyarakat lokal, serta merubah hubungan interpersonal mereka yang akhirnya akan berpengaruh terhadap perubahan interaksi sosial.

Bagi generasi milenial, penggunaan gadget sudah menjadi suatu gaya hidup bahkan bagi generasi milenial media sosial kini menjadi ruang komunikasi. Generasi milenial atau generasi $\mathrm{Z}$ adalah mereka yang lahir setelah tahun 1980, memiliki kecenderungan spesifik pada pandangan politik, komunikasi dan cara pandang terhadap isu-isu dunia.

Tujuan penelitian ini adalah mencari celah untuk menyusun strategi dalam upaya membumikan Pancasila, tidak saja sebagai ideologi negara juga sebagai pandangan hidup, terutama dikalangan anak muda generasi milenial. Sesuai dengan tugas UKP-PIP (Unit Kerja Presiden Pembinaan Ideologi Pancasila) yaitu membatu Presiden dalam merumuskan arah kebijakan umum pembinaan ideologi Pancasila dan melaksanakan koordinasi, sinkronisasi, dan pengendalian pembinaan ideologi Pancasila secara menyeluruh dan berkelanjutan.

Agar nilai-nilai Pancasila dapat ditanamkan pada generasi milenial secara efektif kita perlu mengetahui gambaran generasi milenial tersebut. Berdasarkan hasil Alvara research Center tahun 2014, ketika kita berbicara dan mencoba menggambarkan generasi milenial di Indonesia secara utuh maka setidaknya ada lima isu utama yang perlu dikaji lebih mendalam yakni : 1) Pandangan keagamaan, Religion Beliefs; 2) Ideologi dan partisipasi politik, ideology and politic participation; 3) Nilai-nilai sosial, Social Values; 4) Pendidikan, pekerjaan dan kewirausahaan, education, work and entrepreneurship; 5) Gaya hidup, teknologi, dan internet, lifestyle, technology and internet.

Sudah saatnya sosialisasi nilai-nilai Pancasila juga beserta upaya-upaya pengalamannya dalam kehidupan sehari-hari bertitik tolak dari karakteristik sosok, pola pikir dan aspirasi generasi milenial. Mereka memiliki cara pandangnya sendiri mengenai agama, negara, ideologi dan kaitannya dengan kehidupan berbangsa dan bernegara.

\section{METODOLOGI PENELITIAN}

Metode penelitian pada penelitian ini adalah penelitian kualitatif, data penelitian didapatkan dari hasil studi literatur dan Focus Discussion Group (FDG) yang diadakan oleh UKP-PIP pada tanggal 29 Desember 2017 di Luxton Hotel Bandung. Kegiatan ini dipilih untuk memungkinkan pembicaraan terpusat pada pokok pembicaraan tanpa harus membiarkan forum didominasi oleh peran pembicara. Dalam forum ini setiap peserta pada dasarnya adalah pembicara. Peserta terbatas dengan jumlah sekitar 15 orang. Durasi diskusi sekitas dua jam.

Peserta kegiatan ini adalah kaum muda dari beragam latar komunitas, diantaranya:

1) Anne Rufaidah (Jurnalis ITB); 2) Pitra Moeis (Freelancer); 3) Nichi Hana Karlina (Akademisi UNIBI dan UNPAS); 4) Lulu Mustikaning Apsari (Mahasiswa UPI); 5) Citra Widiantara (Mahasiswa UNPAS); 6) Baban Ganda Purnama (Jurnalis detik.com); 7) Istiqonita (Mahasiswa UIN Sunan Gunung Jati Bandung); 8) Vina (Komunitas Cleanaction); 9) Tata Kartasudjana (Akademisi UNPAS); 10) Fauzan Ibrahin (Siswa SMA Taruna Bakti) ; dan Para staf ahli utama Unit Kerja Presiden Pembinaan Ideologi Pancasila (UKP-PIP), moderator diskusi Dr. Hawe Setiawan.

Tujuan dari FGD ini adalah:

1. Menjaring aspirasi generasi milenial mengenai nilai-nilai Pancasila beserta caracara pengalamannya dalam kehidupan sehari-hari

2. Mempertemukan berbagai kecenderungan pola piker, sikap dan perilaku mengenai agama, negara dan ideologi perekat kesatuan dan persatuan dalam konteks kehidupan kebangsaan di Indonesia

3. Memperdalam ikatan batin generasi milenial pada tatanan kebangasaan Indonesia

\section{HASIL DAN PEMBAHASAN}




\section{a. Latar Belakang Terbentuknya Dan Tugas UKP-PIP}

Unit Kerja Presiden Pembinaan Ideologi Pancasila atau disingkat UKP-PIP adalah Lembaga Nonstruktural yang didirikan pada tahun 2017 melalui Peraturan Presiden (Perpres) Nomor 54 Tahun 2017 tentang Unit Kerja Presiden Pembinaan Ideologi Pancasila. Lembaga ini merupakan unit kerja yang melakukan pembinaan ideologi Pancasila dengan tugas membantu Presiden dalam merumuskan arah kebijakan umum pembinaan ideologi Pancasila dan melaksanakan koordinasi, sinkronisasi, dan pengendalian pembinaan ideologi Pancasila secara menyeluruh dan berkelanjutan. Yudi Latief yang menjabat sebagai ketua, bersama sembilan dewan pengarah lainnya dilantik oleh Presiden Joko Widodo pada tanggal 7 Juni 2017 di Istana Merdeka.

Dalam melaksanakan tugasnya, UKP-PIP menyelenggarakan fungsi:

- Perumusan arah kebijakan umum pembinaan ideologi pancasila

- Penyusunan garis-garis besar haluan ideologi pancasila dan road map pembinaan ideologi pancasila

- Koordinasi, sinkronisasi, dan pengendalian pelaksanaan pembinaan ideologi pancasila

- Pelaksanaan advokasi pembinaan ideologi pancasila

- Pemantauan, evaluasi, dan pengusulan langkah dan strategi untuk memperlancar pelaksanaan pembinaan ideologi pancasila

- Pelaksanaan kerja sama dan hubungan antar lembaga dalam pelaksanaan pembinaan ideologi pancasila.

\section{b. Gambaran Generasi Milenial di Indonesia}

Agar nilai-nilai Pancasila dapat ditanamkan pada generasi milenial secara efektif kita perlu mengetahui gambaran mengenai generasi milenial yang utuh. Menurut Alvara research Center tahun 2014, generasi milenial di Indonesia dapat digambarkan secara utuh dengan mengakaji lebih dalam mengenai lima isu utama yakni: 1) Pandangan keagamaan, Religion Beliefs; 2) Ideologi dan partisipasi politik, ideology and politic participation; 3) Nilai-nilai sosial, Social Values; 4) Pendidikan, pekerjaan dan kewirausahaan, education, work and entrepreneurship; 5) Gaya hidup, teknologi, dan internet, lifestyle, technology and internet.
Pemaparan yang telah disampaikan oleh para narasumber dan juga hasil pembahasan FDG serta data hasil studi literatur akan disusun berdasarkan kelima isu utama diatas.

\section{1) Pandangan Keagamaan Generasi Milenial}

Generasi milenial Indonesia saat ini tengah mengalami gempuran globalisasi Barat. Nilainilai agama yang juga merupakan nilai dari dasar negara sudah semestinya terpatri dalam akal dan jiwa, sehingga muncul kepribadian yang ideologis, saat ini sudah mulai terkikis.

Generasi milenial dapat dengan mudah mengakses ajaran agama dari berbagai sumber, baik dari media cetak maupun media eletronik dan internet. Hadirnya "ulama-ulama" di media sosial dan situs lainnya, memberikan kemudahan generasi milenial dalam memilih narasumber yang dapat membimbing dalam pencariannya dalam memahami ajaran agama. Figur yang menjadi pilihan setidaknya harus memiliki cara penyampaian yang sesuai dengan gaya anak muda milenial seperti dari segi penampilan, gaya bahasa dan pemilihan materi yang disampaikan.

Dalam mencari dan mengkaji mengenai ajaran agama selain di dapatkan melalui internet, generasi milenial pun ternyata masih mendapatkan ilmu agama melalui buku.

Seperti yang disampaikan pada artikel yang dilansir oleh khazanah.republika.co.id, peneliti PPIM UIN Syarif Hidayatullah Jakarta, Prof Jamhari Ma'ruf mengatakan, secara statistik buku-buku keagamaan Islam cukup tinggi diminati generasi milenial. Bahkan pada tahun 2015 buku keagamaan lebih diminati daripada buku-buku novel.

Namun perlu diantisipasi akan adanya bukubuku yang berkonten radikal yang ditulis oleh orang-orang yang berpandangan radikal yang biasanya dikemas dengan cukup menarik dan dapat diperoleh secara instan. 


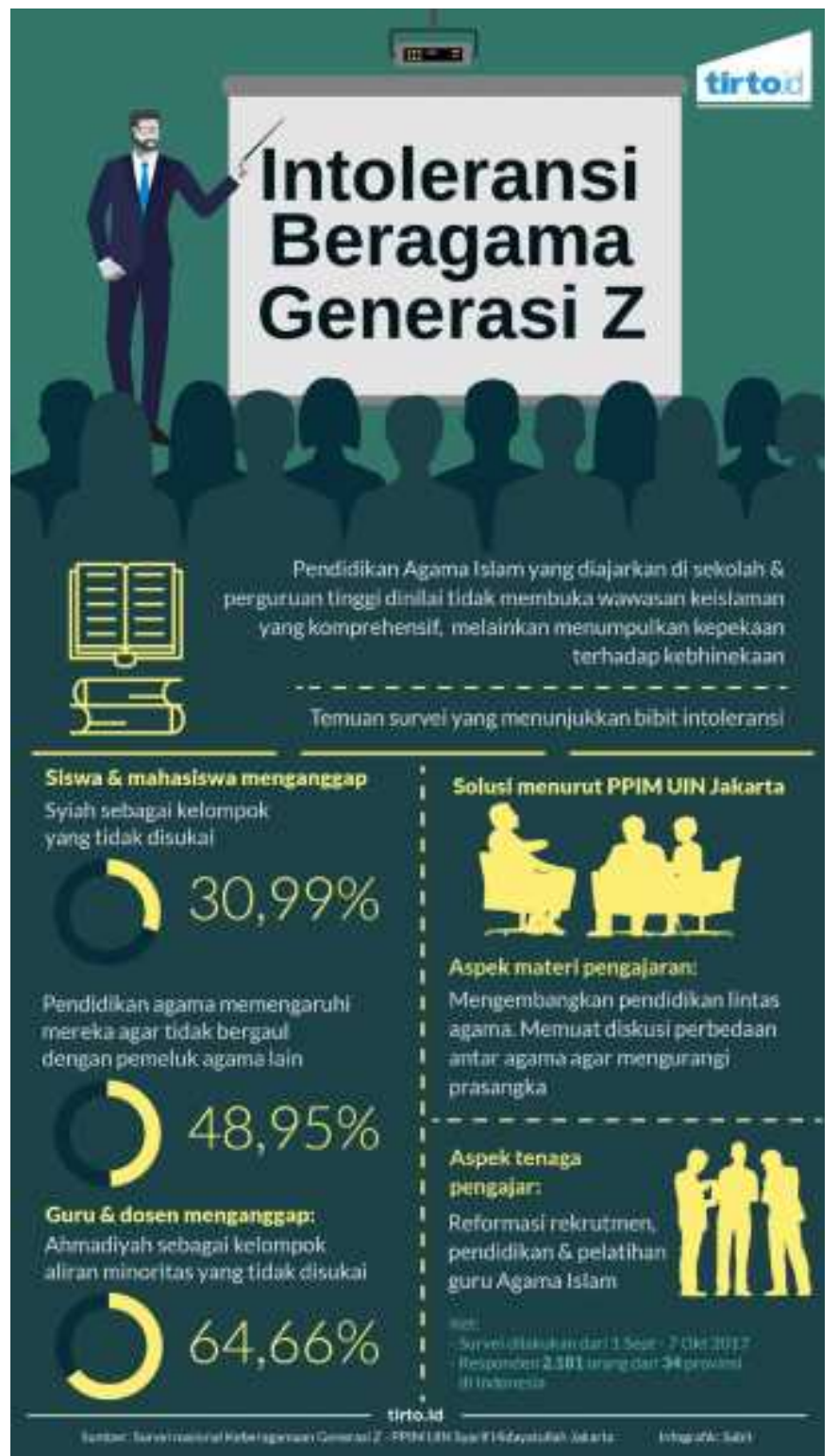

Gambar 2.1.

Infografis Intoleransi Beragama Generasi Z

Sumber : https://tirto.id/gen-z-intoleransi-dan-pembaharuan-pendidikan-agama-islam-cz9Q

Jika buku-buku tersebut menjadi ide anakanak muda di Indonesia, maka akan mempengaruhi dan akan mengganggu konstalasi sosial dan politik. Jadi, kondisi seperti ini harus menjadi keprihatinan bersama.

Generasi milenial dinilai memiliki keterbukaan pemikiran dan toleransi yang cukup tinggi. Namun dalam survei yang dilakukan oleh CSIS (Centre for Strategic and International Studies). yang dilansir oleh Harian Kompas, 28/12/17, disebutkan bahwa sebesar 58,02 persen anak muda menolak dipimpin oleh pemimpin di luar agama. Begitu pun juga dalam hal penerimaan pelaku LGBT.
Bahwa sebesar 78,92 persen dari mereka menyatakan "tidak bisa menerima sama sekali" kelompok LGBT (lesbian, gay, biseksual, dan transjender). Sementara 15,86 persen berkata "kurang menerima" dan hanya 3,96 persen dan 1,26 persen yang menyatakan "cukup menerima" dan "sangat menerima".

Hasil diatas menunjukkan bahwa generasi milenial Indonesia yang dinilai memiliki keterbukaan pemikiran dan toleransi yang tinggi, ternyata masih belum sepenuhnya menerima akan pemimpin di luar agama meraka, juga tidak bertoleransi terhadap pelaku LGBT. 
Berdasarkan survei yang dilakukan oleh Survai Nasional Keberagamaan Generasi ZPPIM UIN Syarif Hidayatullah juga menemukan bibit intoleransi yang diantaranya berasal dari pendidikan Agama Islam yang diajarkan di sekolah \& perguruan tinggi, yang dinilai tidak membuka wawasan keIslaman yang komprehensif, melainkan menumpulkan kepekaan terhadap kebhinekaan.

Jika melihat hasil penelitian dan hasil survei yang lakukan beberapa lembaga survei, didapatkan gambaran dan pandangan generasi milenial mengenai agama. Agama masih menjadi prinsip hidup dan identitas diri generasi milenial Indonesia.

Hal-hal yang berkaitan dengan keagamaan bahkan mampu membentuk trend fashion, pendidikan, entertainment, kuliner, dll, yang potensial untuk dijadikan lahan bisnis. Isu-isu kemanusiaan yang bekaitan dengan agama pun masih menjadi perhatian generasi milenial.

Dengan adanya perubahan kearah digitalisasi dan keterbukaan informasi diharapkan generasi mampu mampu membentengi diri dari hal-hal yang tidak merusak akal dan pikiran. Sehingga generasi milenial Indonesia dapat menjadi sebuah generasi yang unggul dan dapat menjadi penerus bangsa, agama dan negara serta dapat tampil di masa yang akan datang.

\section{2) Milenial Memandang Politik Dan Ideologi}

Penelitian Schwartz mengenai nilai salah satunya bertujuan untuk memecahkan masalah. Setiap tipe nilai merupakan wilayah motivasi tersendiri yang berperan memotivasi seseorang dalam bertingkah laku. Karena itu, Schwartz juga menyebut tipe nilai ini sebagai motivational type of value.

Schwartz (1992, 1994) mengemukakan adanya 10 tipe nilai (value types) yang dianut oleh manusia, yang menjadi motivasi individu. Sepuluh nilai tersebut antara lain kekeluargaan/kebersamaan, kesejahteraan, kemandirian, stabilitas, tradisi, keseragaman, hedonisme, stimulasi, pencapaian/prestasi diri dan kekuasaan.

Untuk mengetahui pandangan masyarakat Indonesia mengenai topik-topik apa saja yang menimbulkan ketertarikan bagi mereka serta nilai motivasi apa yang mendasarinya, Yogrt melakukan sebuah studi. Yogrt merupakan aplikasi pertemanan di platform Android yang dikembangkan khusus di Indonesia, yaitu Yogrt (dibaca Yogurt). Aplikasi yang dikembangkan oleh pengembang Kongko Digital dan Akasanet ini bertujuan untuk memperlancar perkenalan antar-penggunanya.

Diperoleh 5000 responden yang merupakan generasi akar rumput, generasi akar rumput yaitu mereka yang masuk kedalam rentang umur 15-34 tahun dengan penghasilan rumah tangga di bawah Rp.5 juta per bulan dinilai pandangan yang menarik.

Dari hasil studi yang dilakukan oleh Yogrt, hasilnya antara lain; hanya 9 persen responden yang memiliki ketertarikan akan politik, 7 persen responden yang tertarik dengan topik buku. Hiburan menjadi topik yang paling digemari dengan 45 persen responden mengaku tertarik dengan musik dan 30 persen dengan film. Subjek agama juga menarik perhatian 28 persen responden. Subjek agama cukup perhatian, namun alasanya bukanlah untuk pencapaian diri maupun dorongan ideologis, tapi lebih karena keinginan bersosialisasi demi kekeluargaan/kebersamaan.

Dari hasil studi Yogrt tersebut juga menyatakan bahwa pemikiran generasi muda akar rumput di Indonesia terbuka akan pemikiran baru namun enggan untuk mengambil risiko. Alasannya adalah karena nilai kemandirian yang cukup tinggi yang tidak diimbangi dengan nilai stimulasi yang seimbang. 


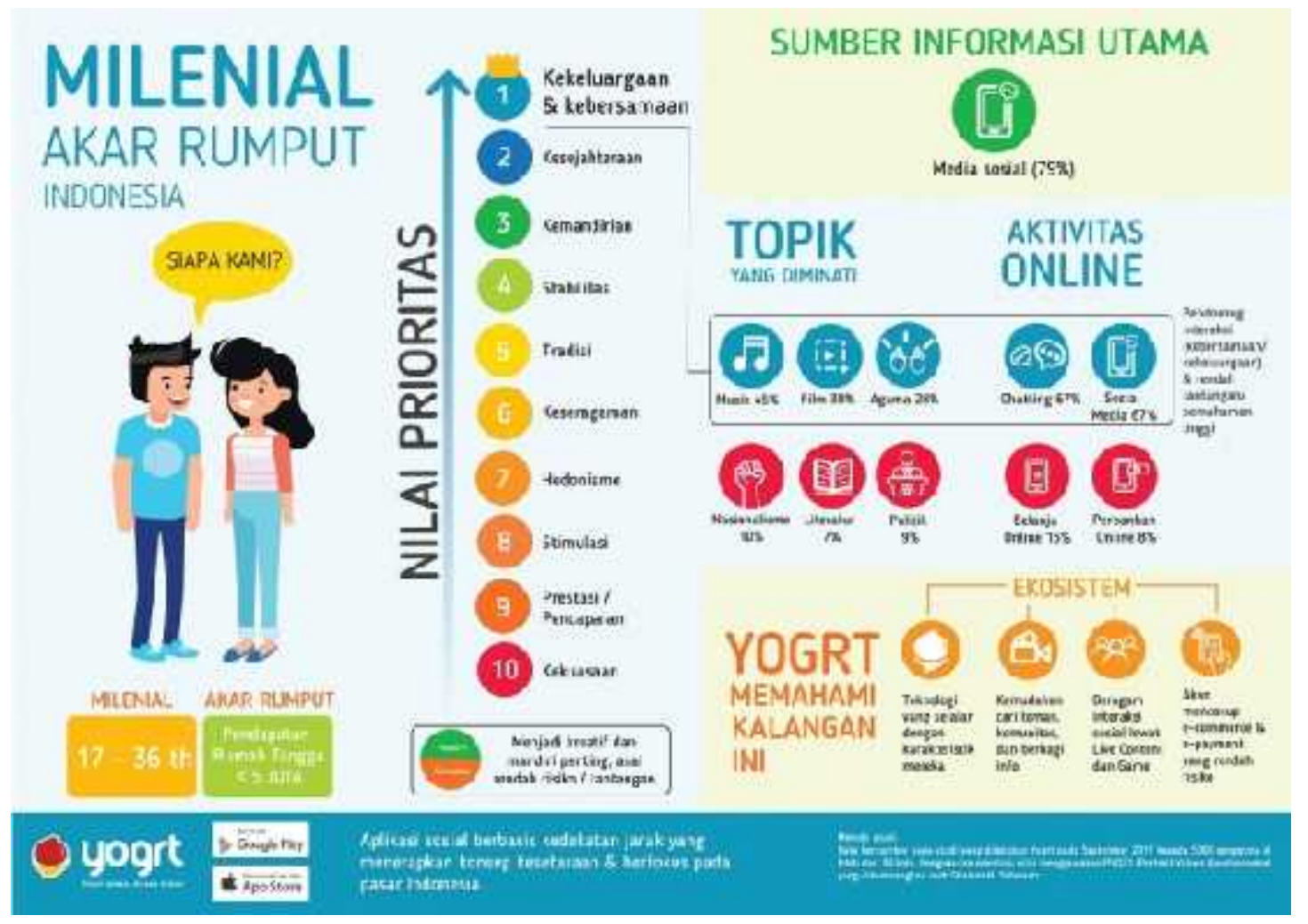

Gambar 2.1 Infografis Milenial Akar Rumput Indonesia

Sumber : http://teknologi.metrotvnews.com/news-teknologi/Rb1ZOyXk-generasi-

milenial-indonesia-kurang-peduli-buku-dan-politik

Meskipun demikian kita mesti mengakui bahwa generasi milenial yang tertarik akan politik, cenderung lebih kritis dalam memilih pemimpinnya, mereka akan memperhatikan latar belakang calon pemimpin, menyaksikan debat dan menunggu hasil perhitungan suara dengan antusias. Mereka akan memilih pemimpin yang dianggap paling kompeten dalam bidangnya atau yang paling meyakinkan untuk bekerja.

Generasi Milenial lebih berani dalam mengkritisi calon/pemimipin melalui kolom komentar di media sosial, mereka berani mendukung ataupun menghujat satu sama lain, namun generasi milenial lebih mudah untuk di provokasi karena mereka jarang mencari tahu kebenarannya, mereka mengetahui berita hanya berdasarkan apa yang disebarkan di internet, sehingga terjadilah fenomena pengalihan atau distraksi melalui internet sebagai suatu kedangkalan cara berpikir (Nicholas. G. Carrr. The Shalow; What The Internet Is Doing To Our Brains).

$\begin{array}{ccc}\text { Pada dasarnya } & \text { masyarakat } & \text { Indonesia } \\ \text { masih berpegang } & \text { teguh akan } & \text { nilai-nilai }\end{array}$

kekeluargaan/kebersamaan, generasi milenial Indonesia pun relatif cukup mudah untuk diarahkan kepada topik apapun, hanya saja perlu diperhatikan kemasan atau cara penyampaiannya agar terlihat menarik, melalui program-program atau wadah ekspresi yang mampu menyalurkan aspirasi mereka dengan cara yang positif dan kreatif, misalnya melalui aplikasi/software yang bertujuan membentuk karakter bangsa yang berlandaskan Pancasila, dengan mengadakan kompetisi musik, tari, seni, desain, olah raga, dll, yang bertujuan untuk menumbuhkan nilai-nilai Pancasila.

Generasi milenial juga perlu diberikan arahan, kepercayaan dan dukungan sehingga dapat memberikan mereka kebebasan dalam berpendapat namun penuh tanggung jawab. Tentunya arahan dan kepercayaan tersebut salah satunya berasal dari pemerintah yang dapat diwakili oleh sosok/figur yang mampu memberikan contoh/role model penerapannya.

\section{3) Peran Keluarga, Komunitas dan Organisasi Dalam Penanaman Nilai-Nilai Sosial}

Berinteraksi dan bersosialisasi dengan orang lain merupakan kebutuhan dasar kita sebagai 
makhluk sosial, yang telah ada pada diri setiap manusia sejak lahir ke dunia. untuk menjaga kerukunan Dalam berinteraksi, kita memerlukan kebersamaan dan kekompakan satu sama lain, agar dapat berjalan dengan lancar dan terhindar dari berbagai konflik. Untuk mewujudkan ketentraman dan kedamaian dalam suatu masyarakat diperlukn rasa saling pengertian antar individu.

Mempererat kebersamaan dan kekompakan dapat dilakukan melalui beberapa cara, diantaranya melalui keluarga, komunitas dan organisasi.

Peran keluarga sangatlah penting dalam penanaman nilai-nilai sosial. Keluarga adalah bagian masyarakat yang paling kecil. Nilai-nilai sosial yang paling dasar seharusnya dibangun di dalam keluarga. Seluruh anggota keluarga seharusnya menjalankan perannya masingmasing. Namun pada generasi milenial saat ini peran-peran tersebut sudah tidak bisa terlakasana dengan baik.

Berdasarkan data diri sebuah lembaga survei Statista yang dilansir oleh tirto.id, ditemukan baha $61 \%$ orang tua memberikan smartphone/tablet untuk anaknya $(<18)$ sebagai pengganti tugas mengasuh, dimana seharusnya pengasuhan dilakukan oleh orang tua. Keputusan itulah yang mengakibatkan hilangnya sosok/figur orang tua yang seharusnya menjadi role model.

Peran dari orang tua sangatlah krusial. Orang tua merupakan role model karakter yang menjadi panutan anaknya kelak. Terlebih dalam taraf perkembangan sang anak dimana fase contoh gerak-gerik dan tingkah laku dari orang disekitar begitu kuat, maka peran orang tua seharusnya mampu menjadi sentral teladan role model dibandingkan lingkungan sekitarnya. Lalu jika sosok/figure orang tua tidak ada bagaimana?

Menurut psikolog Cecilia Evi, hilangnya sosok salah satu orang tua, anak akan mengalami ketimpangan dalam memahami peran orang tua yang utuh. Mereka tidak memperoleh kesempatan untuk belajar dan mengalami kasih sayang, pengasuhan atau pendampingan dari figur ayah/ibu. Mereka juga cenderung memiliki kebutuhan afeksi yang lebih besar, karena ada bagian dalam dirinya yang terasa tidak lengkap, apalagi jika dia mencari sendiri figur orang tua di internet, maka tidak heran jika generasi milenial memiliki kepribadian yang labil dan mudah di provokasi.
Maka perlu diperhatikan agar ayah ibu dapat berbagi peran yaitu komunikasi terkait kesepakatan mengenai pola pengasuhan, saling mendukung satu sama lain, dan komitmen dari orangtua di tengah kesibukan. Sebelum menyepakati pola pengasuhan yang akan dipilih, para orang tua terutama orang tua yang memiliki anak yang termasuk kedalam generasi milenial juga harus memilki ilmu yang terkait dengan pola pengasuhan atau ilmu parenting.

Ilmu parenting yang harus diketahui oleh para orang tua tersebut perlu di sosialisasikan dalam sebuah program yang perlu dicanangkan bersama oleh pemerintah dan pihak-pihak yang terkait, agar orang tua dari generasi milenial di Indonesia mampu mempersiapkan diri dan mampu menyesuaikan pola pengasuhannya dengan kondisi gempuran teknologi saat ini dan tetap dapat menciptakan generasi bangsa Indonesia yang berjiwa Pancasila.

Selain melalui keluarga, penanaman nilainilai sosial pun daapt diperoleh melalui komunitas. Dalam sebuah komunitas, pada umumnya anggota-anggotanya memiliki kegemaran yang sama. Dari kesamaan hobi atau kegemaran inilah anggota-anggota dalam suatu komunitas dapat menjalin pertemanan. Acaraacara yang diselenggarakan dalam sebuah komunitas umumnya berfokus pada tujuan untuk mempererat kebersamaan antar anggotanya.

Sedangkan organisasi merupakan wadah/sarana bagi suatu kelompok individu yang minimal punya suatu kesamaan visi dan misi. Untuk mempertahankan keberadaan oraganisasi dibutuhkan loyalitas dan juga kerbersaan dari para anggotanya. Loyalitas erat kaitannya dengan kesetiaan. Seorang anggota yang memiliki loyalitas terhadap organisasinya memiliki kesadaran pribadi untuk memanfaatkan semua potensi yang ada dalam dirinya demi kemajuan organisasi, anggota tersebut akan menaati segala bentuk tata tertib yang berlaku, mendukung program kerja dengan mengikutsertakan diri sebagai partisipan aktif. Bahkan menjadi pengurus/kreator ide-ide penting untuk membangun organisasi dari dalam.

Generasi milenial dikenal dengan sikapnya yang acuh tak acuh atau kurang peduli terhadap masalah-masalah sosial, hal tersebut tidak sepenuhnya benar. Dengan terbentuknya komunitas-komunitas dan organisasi-organisasi di Indonesia terutama di kota-kota besar khususnya yang bergerak di bidang sosial 
sebagai buktinya. Komunitas dan organisasi menjadi pilihan generasi milenial sebagai wadah untuk eksisensi, juga tempat untuk bertukar informasi sekaligus tempat untuk menguatkan diri, juga untuk berdedikasi dalam pengentasan masalah sosial.

Komunitas serta organisasi yang bergerak di bidang sosial bisasanya dicanangkan oleh individu-individu yang memiliki keresahan terhadap permasalahan sosial yang ada disekitarnya yang terkadang luput dari perhatian pemerintah. Kemudian mereka membuat sebuah visi dan misi yang mereka wujudkan dalam sebuah kegiatan/program yang dapat membantu dan menolong sesama terutama bagi orang-orang yang membutuhkan.

Kegiatan/program yang mereka didedikasikan untuk bangsa dan negara tersebut, pada kenyataannya adalah implementasi dari penerapan nilai-nilai Pancasila dalam kehidupan nyata namun seringkali tidak mereka sadari. Bahkan dengan adanya komunitas-komunitas dan organisasiorganisasi yang bergerak dalam bidang sosial tersebut pada kenyataannya dapat membantu tugas pemerintah dalam mengatasi masalahmasalah sosial dan juga secara tidak langsung membantu dalam proses penanaman nilai-nilai Pancasila pada generasi milenial Indonesia. Maka keadaan tersebut perlu menjadi perhatian dan perlu dicermati oleh pemerintah.

Keberadaan komunitas-komunitas dan organisasi-organisasi sosial tersebut perlu di dukung dan dirangkul serta di berikan peluang untuk bekerjasama terutama untuk programprogram pemerintah yang sejalan dengan visi, misi komunitas-komunitas atau organisasiorganisasi tersebut.

Dengan adanya kerjasama yang terjalin antara komunitas, organisasi dan pemerintah diharapkan dapat mewujudkan generasi muda yang memiliki loyalitas yang tinggi dan nilainilai Pancasila dapat terpatri dengan baik di jiwa para generasi milenial.

\section{4) Milenial Berpendidikan, Bekerja Dan Berwirausaha}

Generasi milenial rata-rata memiliki tingkat pendidikan lebih baik dibanding generasi sebelumnya, terutama didukung dengan program pemerintah Wajib Belajar 12 tahun. Melalui pendidikan formal pembentukan karakter bangsa dengan menanamkan nilai-nilai Pancasila masih harus diterapkan, hanya mungkin saja dengan cara yang berbeda, penyampaian nilai-nilai Pancasila perlu disertai dengan implementasiya di dalam kehidupan sehari-hari. Maka pengembangan kurikulum yang berkaitan dengan mata pelajaran Pancasila perlu dilakukan dengan menerapkan 'praktek lapangan'. Indikator penilaiannya perlu dikembangkan, jenis praktek lapangan seperti apa yang tepat juga perlu di kaji kembali.

Pemanfaatan teknologi digital dan internet juga sudah mulai diterapkan dalam proses belajar mengajar dengan diadakannya program e-learning, dimana proses belajar-mengajar dapat dilakukan di luar kelas, dan penyampaian materi, diskusi dan tugas-tugas, dapat disampaikan secara online.

Begitupun dengan kesempatan membuka usaha dan bekerja pun lebih banyak. Dengan perkembangan teknologi kegiatan-kegiatan dapat diakses lebih mudah dan cepat, serta jaringan pun lebih luas dan peluang usaha untuk meningkatkan penghasilan pun lebih luas. Dengan berkembangnya teknologi membuka banyak peluang usaha baru yang berbasis internet seperti transportasi online, jual beli online, tiket online, dll.

Dengan akses internet berbagai informasi dan ilmu pengetahuan dapat kita dapatkan dengan mudah, sehingga generasi milenial pun dapat menjalankan proses belajar, bekerja dan berwirausaha di manapun dan kapanpun.

Bagi calon pekerja dapat juga diadakan tes dan pelatihan untuk menanamkan nilai-nilai kepemimpinan, loyalitas dan tanggung jawab.

\section{5) Gaya Hidup Milenial}

Generasi milenial dengan koneksinya terhadap teknologi digital membuat pola gaya hidup baru di Indonesia, diantaranya : milenial lebih menyukai transaksi dengan cashless. Berkaitan dengan semakin banyaknya fasilitas yang mengharuskan kita menggunakan uang digital seperti pada Gerbang Pintu Tol, Commuterline, dll, sehingga merasa lebih aman dan praktis.

Gaya hidup generasi milenial relatif konsumtif bahkan hedon. Ini merupakan perubahan besar. Indonesia dikenal dengan keramahan dan kesederhanaanya, kini relatif lebih konsumtif dan mewah. Hal tersebut di dukung juga dengan perkembangan teknologi dan internet, kegiatan jual beli dapat dilakukan secara online dimana pun dan kapan pun, hal tersebut membuat konsumen merasa nyaman dan aman dalam bertransaksi juga menghemat waktu dan tenaga juga mampu memberikan 
banyak referensi dalam satu waktu. Meskipun berbelanja online masih belum bisa menggantikan gaya berbelanja pola lama, dimana barang dapat dilihat, disentuh dan dicoba secara langsung, serta proses transkasi dilakukan antara penjual dan pembeli langsung di tempat.

Gaya fashion generasi milenial benar-benar dipengaruhi oleh figur yang ditampilkan melalui media sosial. Tempat wisata yang dipilih biasanya yang menyajikan keindahan alam yang memiliki spot khusus untuh berfoto yang kemudian akan di sebarkan melalui media sosial.

Begitupun dengan kemudahan transportasi, dengan adanya taxi atau ojek berbasis aplikasi yang terhubung dengan internet, memudahkan masyarakat untuk berpergian, hanya tinggal sentuh di layar smartphone, kemudian layanan transportasi akan menjemput dan mengantar kita sesuai lokasi yang diinginkan.

Perkembangan teknologi yang sangat pesat ini membuat gaya hidup generasi milenial berubah drastis, maka upaya penyampaian informasi terutama dalam penanaman nilai-nilai Pancasila pun perlu pengembangan menyesuaikan dengan gaya hidup dan teknologi yang paling di minati oleh generasi milenial.

\section{KESIMPULAN}

Berdasarkan hasil penelitian didapatkan beberapa hal yang perlu dipertimbangkan untuk merancang strategi diantaranya perlu adamya; 1) Pembinaan yang berkesinambungan antara penanaman nilainilai Pancasila melalui keluarga, komunitas serta organisasi dan penanaman nilai-nilai Pancasila melalui pendidikan formal tidak hanya dengan teori tapi juga diimplementasikan langsung kedalam kehidupan sehari-hari. 2) Perlu adanya Rebranding mengenai Pancasila agar Pancasila memiliki citra baru yang mampu menarik perhatian generasi milenial, 3) Sosok/figur yang mampu menjadi role model yang dapat merepresentasikan nilai-nilai Pancasila, namun harus benar-benar dipilih berdasarkan kriteria sosok/figur yang sedang digandrungi oleh generasi milenial tersebut juga harus mempunyai kompetensi dan kredibiltas yang baik; 4) Membuat program/aktivitas kreatif bertemakan Pancasila; 5) Pemanfaatan teknologi dan media sosial sebagai alat pendukung sosialisasi dan komunikasi; 6) Kerjasama antara komunitas yang bergerak dalam bidang sosial yang sudah ada dengan pemerintah pusat.

Dengan mengetahui mengenai gambaran genarasi milenial, diharapkan kita mampu memabangun sebuah strategi yang tepat dalam mengupayakan agar nilai-nilai Pancasila dapat tertanamkan dengan subur dan dapat menciptakan generasi-generasi Indonesia yang berbudi luhur yang berlandaskan Pancasila.

\section{REFERENSI}

Piliang, Yasraf Amir. 2011. Terkurung di Antara Realitas-realitas Semu. Dunia Yang Dilipat, 159, 170, 176. Bandung: Matahari

Schwartz, S. H.; Verkasalo, M.; Antonovsky, A.; Sagiv, L. 1997. Value Priorities and Social Desirability : Much Substance, Some Style. British Journal of Social Psychology, 36, $3-18$

Peraturan Presiden Republik Indonesia Nomor 54 Tahun 2017 Tentang Unit Kerja Presiden Pembinaan Ideologi Pancasila

Ellavie Ichlasa Amalia. 2017. Generasi Milenial Indonesia Kurang Peduli Buku dan Politik.http://teknologi.metrotvnews.com/ne ws-teknologi/Rb1ZOyXk-generasi-milenialindonesia-kurang-peduli-buku-dan-politik. Diakses pada 12 Januari 2018.

Fuji E Permana dan Esthi Maharani. 2018. Generasi Milenial Minati Buku-Buku Agama.

http://khazanah.republika.co.id/berita/duniaislam/islam-nusantara/18/01/11/p2cnmv335generasi-milenial-minati-bukubuku-agama. Diakses pada 11 Januari 2018

Milenial. 2017. Generasi Milenial Dalam Identitas Sebuah Agama. http://www.milenial.co.id/2018/01/03/gener asi-milenial-dalam-identitas-sebuah-agama/. Diakses pada 11 Januari 2018.

Terry Muthahhari. 2017. Gen-Z, Intoleransi dan Pembaharuan Pendidikan Agama Islam. https://tirto.id/gen-z-intoleransi-dan pembaharuan-pendidikan-agama-islamcz9Q. Diakses pada 12 Januari 2018 
e-ISSN: 2597-5188

Vol.1, No.1, April 2018 